\title{
Carabid beetles (Coleoptera: Carabidae) in several types of forests on Hokkaido, Japan, with implications for forest management practices and beetle preservation
}

\author{
JUN KAIZUKA ${ }^{1,2}$, TAMAKI YAMAGUCHI ${ }^{1,3}$ and MITSUHIRO IWASA ${ }^{1}$ \\ ${ }^{1}$ Laboratory of Entomology, Obihiro University of Agriculture and Veterinary Medicine, Obihiro, Japan; \\ e-mail: iwasa@obihiro.ac.jp \\ ${ }^{2}$ Chodai Co., Ltd., Higashi 2-5-3, Kita 1, Chuo-ku, Sapporo, Hokkaido, 060-0031 Japan; e-mail: kaizuka-j@chodai.co.jp \\ ${ }^{3}$ Docon Co., Ltd., 4-9 Kodenmatyoushinnihonbashi Bld., Nihonbashikodenmacho, Chuo-ku, Tokyo, 103-0001, Japan; \\ e-mail: ty1635@docon.jp
}

\begin{abstract}
Key words. Coleoptera, Carabidae, carabid beetles, forest management, conifer plantation, forest specialist, mixed forest, conservation, Japan, Hokkaido

Abstract. This study of the role the environment in the composition of the communities of carabid beetles was carried out in several types of forests at Obihiro and Furano, Hokkaido, Japan. In addition, we analysed the altitudinal distributions of two forest specialists, Damaster gehinii (Faimaire) and Procrustes kolbei Roeschke, which occur in six mountain forests on Hokkaido. At Obihiro, the forest specialist, $P$. kolbei was found at only one site in a large area of broadleaf forest. A redundancy analysis indicated that the carabid assemblages were significantly different in the different types of forest, and that two species, Leptocarabus arboreus arboreus (Lewis) and Leptocarabus opaculus opaculus (Putzeys), were associated with broadleaf forests. At Furano, a forest specialist $D$. gehinii and a forest generalist $C y$ chrus morawitzi Gehin were mainly collected in natural broadleaf and mixed forests, whereas the percentage made up of $L$. 0 . opaculus was very high $(80.8 \%)$ in natural broadleaf forest. Pterostichus thunbergii Morawitz made up the highest percentage of the species in the conifer plantations. In the six mountain forests, $D$. gehinii was scarce and mainly occurred at low altitudes; however, $P$. kolbei was relatively abundant and mainly recorded at middle to high altitudes. The management of the forests on Hokkaido needed to maintain the diversity and abundance of carabid beetles is discussed.
\end{abstract}

\section{INTRODUCTION}

Japan is a country where two-thirds of the land is covered by forest of which $40 \%$ consists of plantations mainly composed of cryptomeria and Japanese cypress (Ministry of Agriculture, Forestry and Fisheries, 2018). On Hokkaido, more than $70 \%$ of the land is covered with forests, almost all of which are natural except at high altitudes where there are secondary broadleaf forests and conifer plantations (Hokkaido Government, 2018). In terms of forestry management, forest biota are not considered. Logging and reforestation fragment the landscape and can affect the composition of arthropod communities (Duchesne et al., 1999; Kotze \& Samways, 1999; Werner \& Raffa, 2000; Müller et al., 2002; Waltz \& Covington, 2004; Koivula \& Spence, 2006; Cobb et al., 2007). Reducing the effect of afforestation on arthropods in forest ecosystems is an important issue that needs to be considered by forest managers.

Carabid beetles (Coleoptera: Carabidae) are diverse and abundant, have relatively well known ecologies and systematics and are easy to collect using pitfall traps (Eyre et al., 1996; Lövei \& Sunderland, 1996; Niemelä et al.,
2000; Werner \& Raffa, 2000). Moreover, they are sensitive to environmental factors and respond rapidly to habitat changes (Osawa et al., 2005; Shibuya et al., 2008, 2014), because they are poor at dispersing as they have vestigial hind wings (Niemelä, 1997; Duchesne et al., 1999; Yu et al., 2002, 2006). Thus, they are used as bio-indicators in investigations into the biodiversity in forests managed in different ways in Europe (Humphrey et al., 1999; Magura et al., 2000, 2001a; Koivula, 2002b; Finch, 2005; Lövei et al., 2006; Karen et al., 2008; Lange et al., 2014; Negro et al., 2014), Africa (Rainio \& Niemelä, 2006), Central and North America (Klimaszewski et al., 2005; Ulyshen et al., 2006) and Japan (Fujita et al., 2008; Kaizuka \& Iwasa, 2015).

Many studies on carabid assemblages in forests have been on various issues, such as age of forests and effect of replanting after logging and deforestation (Baguette \& Gerard, 1993; Fahy \& Gormally, 1998; Ings \& Hartley, 1999; Baker, 2006); effects of fragmentation on assemblages (Halme \& Niemelä, 1993; Fujita et al., 2008); effect of edges between forest and clear-cut grassland (Heliölä et 
al., 2001; Magura et al., 2001b; Magura, 2002) and comparison of conifer and broadleaf forests (Butterfield et al., 1995; Fuller et al., 2008; Yu et al., 2008). The differences between carabid assemblages in various landscapes are also reported in ecotones between natural forests and mature pine forests (Yu et al., 2010), urban landscapes (da Silva et al., 2008; Do et al., 2012) and farmland (Purtauf et al., 2005). The clear-cutting of native forests and planting non-native species of trees in clear-cut areas have unfavourable effects on the species diversity and abundance of carabids (Fahy \& Gormally, 1998; Magura et al., 2000, 2002; Yu et al., 2006). However, the response of carabid beetles to changes in forests depends on their location. Further knowledge on carabid assemblages in various types of forests is required for conservation and management of forest. There is also little information on the altitudinal distributions of carabid. The aim of this study is to collect data on carabid beetles for evaluating the conservation value of typical forests on Hokkaido, Japan, and recommend how these forests should be managed in order to safeguard the carabid assemblages in mountain areas. First, the carabid assemblages in the secondary broadleaf forests, secondary mixed forests of broadleaf and conifer trees and the conifer (Sakhalin fir) plantations at Obihiro in eastern Hokkaido were recorded. All these sites were originally natural deciduous forests, which were felled and replanted. Second, we compared the composition of the carabid assemblage in a natural broadleaf forest, a natural mixed forest and conifer plantation at Furano in central Hokkaido. Third, the altitudinal distributions of two forest specialists (Damaster gehinii (Faimaire) and Procrustes kolbei Roeschke) that inhabit natural or mature forest on six mountains in central to eastern Hokkaido were analysed using insect collections in the Laboratory of Entomology at Obihiro University of Agriculture and Veterinary Medicine.

\section{MATERIALS AND METHODS}

Carabid beetles in secondary broadleaf forests, mixed forests and conifer plantations at Obihiro

Study area and sampling

The area studied is located at the foot of the Hidaka Mountain range in the suburbs of Obihiro City in the eastern part of Hok- kaido, northern Japan. The area is mainly surrounded by secondary broadleaf forests, secondary mixed forests, and conifer plantations, and the Tottabetsu river and its tributaries. Three types of forests were sampled with three replicates in each: (1) secondary broadleaf forest, (2) secondary mixed forest and (3) conifer plantation (Table 1). The sample sites were located at an altitude of 425-650 $\mathrm{m}$ (Table 1). The areas were each between 0.9-30.2 ha in size: $2.7-30.2$ ha for the secondary broad leaf forest, 0.9-4.9 ha for the secondary mixed forest and $1.1-2.5$ ha for the conifer (Sakhalin fir) plantation and in terms of the age of the trees were between 40-50 years after regrowth or replanting of each site. Although there is a difference in the age of the trees at the different sites, stands of pine that are between 21-60 years old are usually regarded as in the same age class (Baguette \& Gerard, 1993; Niemelä et al., 1994), so all the sites studied were considered to be in the same age class.

Ground beetles were sampled using baited pitfall traps $(8 \mathrm{~cm}$ in diameter and $9.5 \mathrm{~cm}$ deep with two small holes high up on the sides to drain excess rainwater) containing $20 \mathrm{~mL}$ of a solution of water, brown sugar, acetic acid and ethanol in the ratio $6: 2: 1: 1$ (Kimoto \& Yasuda, 1995). Six needles were fixed to the top of each trap to deter wild animals from damaging the traps. Fifteen traps were set at least $50 \mathrm{~m}$ from the forest edge in order to avoid "edge effects" (Magura et al., 2001b) with a distance of about 2-3 $\mathrm{m}$ between traps and with their openings level with the ground surface. During this survey, 135 traps were used. Samples were collected at 2-week intervals from 18 June to 26 August 2016. As the area studied was destroyed by 3 typhoons $(17,21$, and $23 \mathrm{Au}-$ gust), we only used the results recorded in the period prior to the first typhoon Carabid beetles collected at each site were pooled, and the number of beetles caught per trap was calculated only for traps that were not disturbed by wild animals. Pooled samples were identified to species according to Ueno et al. (1985). Some remarkable or representative species were categorized as "forest specialists" or "forest generalists" using habitat data of Kimoto \& Yasuda (1995), Hori (2003) and Working Group for Biological Indicator Ground Beetles Database Japan (2015). According to Jukes et al. (2001), the two categories are defined as follows: forest specialist are species with a strong affinity for forest habitats such as natural or mature forest; forest generalist are those associated with a wider range of forest habitats, including scrub and hedgerows.

\section{Environmental variables and analysis}

Percentage understory cover and canopy cover were assessed at one point per site within a radius of $5 \mathrm{~m}$ in July 2016. Soil moisture was measured at a depth of approximately $5 \mathrm{~cm}$ in the

Table 1. Details of the sites where carabid beetles were sampled at Obihiro and Furano.

\begin{tabular}{|c|c|c|c|c|c|c|c|}
\hline Forest types & $\mathrm{n}$ & Sites & Locations & $\begin{array}{l}\text { Altitude } \\
(\mathrm{m})\end{array}$ & $\begin{array}{c}\text { Area } \\
\text { (ha) }\end{array}$ & $\begin{array}{c}\text { Canopy } \\
\text { cover }(\%)\end{array}$ & $\begin{array}{c}\text { Understory } \\
\text { cover }(\%)\end{array}$ \\
\hline \multicolumn{8}{|l|}{ Obihiro } \\
\hline & & 1 & $42^{\circ} 42^{\prime} 59 \mathrm{~N}, 142^{\circ} 52^{\prime} 53 \mathrm{E}$ & 650 & 30.2 & 70 & 80 \\
\hline \multirow[t]{3}{*}{ Secondary broadleaf forest (Bro) } & 3 & 2 & $42^{\circ} 44^{\prime} 29 \mathrm{~N}, 142^{\circ} 52^{\prime} 10 \mathrm{E}$ & 470 & 3.7 & 85 & 70 \\
\hline & & 3 & $42^{\circ} 43^{\prime} 59 \mathrm{~N}, 142^{\circ} 53^{\prime} 26 \mathrm{E}$ & 425 & 2.7 & 80 & 85 \\
\hline & & 1 & $42^{\circ} 43^{\prime} 54 N, 142^{\circ} 52^{\prime} 53 E$ & 483 & 4.9 & 70 & 70 \\
\hline \multirow[t]{3}{*}{ Secondary mixed forest (Mix) } & 3 & 2 & $42^{\circ} 44^{\prime} 26 \mathrm{~N}, 142^{\circ} 52^{\prime} 10 \mathrm{E}$ & 475 & 2.6 & 75 & 85 \\
\hline & & 3 & $42^{\circ} 44^{\prime} 10 \mathrm{~N}, 142^{\circ} 52^{\prime} 58 \mathrm{E}$ & 448 & 0.9 & 75 & 80 \\
\hline & & 1 & $42^{\circ} 44^{\prime} 03 \mathrm{~N}, 142^{\circ} 52^{\prime} 56 \mathrm{E}$ & 457 & 1.1 & 60 & 95 \\
\hline \multirow[t]{2}{*}{ Conifer (Sakhalin fir) plantation (Con) } & 3 & 2 & $42^{\circ} 44^{\prime} 21 \mathrm{~N}, 142^{\circ} 52^{\prime} 00 \mathrm{E}$ & 495 & 2.5 & 65 & 90 \\
\hline & & 3 & $42^{\circ} 44^{\prime} 27 \mathrm{~N}, 142^{\circ} 52^{\prime} 28 \mathrm{E}$ & 458 & 1.5 & 55 & 100 \\
\hline \multicolumn{8}{|l|}{ Furano } \\
\hline Natural broadleaf forest (NB) & 1 & - & $43^{\circ} 12^{\prime} 44 \mathrm{~N}, 142^{\circ} 28^{\prime} 22 \mathrm{E}$ & 380 & 6.9 & 35 & 80 \\
\hline Natural mixed forest (NM) & 1 & - & $43^{\circ} 12^{\prime} 49 \mathrm{~N}, 142^{\circ} 28^{\prime} 27 \mathrm{E}$ & 406 & 3.4 & 30 & 55 \\
\hline Conifer plantation (PL) & 1 & - & $43^{\circ} 12^{\prime} 44 \mathrm{~N}, 142^{\circ} 28^{\prime} 22 \mathrm{E}$ & 355 & 4.3 & 85 & 10 \\
\hline
\end{tabular}


Table 2. Locations and dominant species of trees in canopy and plants in the understory at sites sampled for carabid beetles on six mountains.

\begin{tabular}{|c|c|c|c|c|c|c|c|}
\hline \multirow{3}{*}{ Mountain } & \multirow{3}{*}{$\begin{array}{l}\text { Maximum } \\
\text { altitude } \\
\text { Latitude } \\
\text { Longitude }\end{array}$} & \multicolumn{3}{|c|}{ Dominant species of trees } & \multicolumn{3}{|c|}{ Dominant species of understory plants } \\
\hline & & \multicolumn{6}{|c|}{ Altitudinal categories } \\
\hline & & $\begin{array}{c}\text { Low } \\
\text { Below } 700 \mathrm{~m}\end{array}$ & $\begin{array}{c}\text { Middle } \\
700-1,400 \mathrm{~m}\end{array}$ & $\begin{array}{c}\text { High } \\
\text { Above } 1,400 \mathrm{~m}\end{array}$ & $\begin{array}{c}\text { Low } \\
\text { Below } 700 \mathrm{~m}\end{array}$ & $\begin{array}{c}\text { Middle } \\
700-1,400 \mathrm{~m}\end{array}$ & $\begin{array}{c}\text { High } \\
\text { Above } 1400 \mathrm{~m}\end{array}$ \\
\hline $\begin{array}{l}\text { Tokachi- } \\
\text { Poroshiri }\end{array}$ & $\begin{array}{c}1,846 \mathrm{~m} \\
42^{\circ} 41^{\prime} 44 \mathrm{~N} \\
142^{\circ} 51^{\prime} 33 \mathrm{E} \\
\end{array}$ & & Betulaceae & \multirow{6}{*}{$\begin{array}{c}\text { Betulaceae } \\
\text { Betula ermanii } \\
\text { Pinaceae } \\
\text { Pinus pumila }\end{array}$} & \multirow{3}{*}{\multicolumn{2}{|c|}{$\begin{array}{c}\text { Poaceae } \\
\text { Sasa senanensis }\end{array}$}} & \multirow{6}{*}{$\begin{array}{l}\text { Ericaceae } \\
\text { Empetrum nigrum } \\
\text { japonicum } \\
\text { Vaccinium } \\
\text { vitis-udaea }\end{array}$} \\
\hline Fushimi & $\begin{array}{c}1,792 \mathrm{~m} \\
42^{\circ} 46^{\prime} 34 \mathrm{~N} \\
142^{\circ} 45^{\prime} 56 \mathrm{E} \\
\end{array}$ & $\begin{array}{c}\text { Betulaceae } \\
\text { Alnus maximowiczii }\end{array}$ & $\begin{array}{l}\text { Alnus } \\
\text { maximowiczii } \\
\text { Betula ermanii }\end{array}$ & & & & \\
\hline Memuro & $\begin{array}{c}1,754 \mathrm{~m} \\
42^{\circ} 52^{\prime} 8 \mathrm{~N} \\
142^{\circ} 47^{\prime} 7 \mathrm{E}\end{array}$ & $\begin{array}{c}\text { Betula platyphylla } \\
\text { Pinaceae } \\
\text { Picea jezoensis }\end{array}$ & $\begin{array}{l}\text { Pinaceae } \\
\text { Picea jezoensis } \\
\text { Picea glehnii }\end{array}$ & & & & \\
\hline Shari & $\begin{array}{c}1,547 \mathrm{~m} \\
43^{\circ} 45^{\prime} 57 \mathrm{~N} \\
144^{\circ} 43^{\prime} 3 \mathrm{E} \\
\end{array}$ & $\begin{array}{l}\text { AbIes sachalınensis } \\
\text { Salicaceae } \\
\text { Populus suaveolens }\end{array}$ & $\begin{array}{c}\text { Abies } \\
\text { sachalinensis } \\
\text { Fagaceae }\end{array}$ & & \multirow{3}{*}{\multicolumn{2}{|c|}{$\begin{array}{c}\text { Poaceae } \\
\text { Sasa kurilensis }\end{array}$}} & \\
\hline Yûbari & $\begin{array}{c}1,668 \mathrm{~m} \\
43^{\circ} 5^{\prime} 59 \mathrm{~N} \\
142^{\circ} 15^{\prime} 4 \mathrm{E} \\
\end{array}$ & & Quercus crispula & & & & \\
\hline Rakko & $\begin{array}{c}1,471 \mathrm{~m} \\
42^{\circ} 16^{\prime} 20 \mathrm{~N} \\
143^{\circ} 40^{\prime} 49 \mathrm{E}\end{array}$ & $\begin{array}{c}\text { Ulmaceae } \\
\text { Ulmus davidiana } \\
\text { var. japonica } \\
\text { Sapindaceae } \\
\text { Acer pictum ssp. mono }\end{array}$ & $\begin{array}{l}\text { Rosaceae } \\
\text { Sorbus commixta } \\
\text { Betulaceae } \\
\text { Betula platyphylla }\end{array}$ & & & & \\
\hline
\end{tabular}

centre of each site once a month during the sampling period using a ProCheck Handheld Reader (Decago Devices, Inc., Pullman, WA, USA).

We determined the associations between five environmental variables (canopy cover, understory cover, size of area, soil moisture and type of forest) and the numbers of species and individuals. We used generalized linear models (GLM) with Poisson error distributions and log link functions (glm function of package) In the GLM, the numbers of species and individuals were used as a response variables, and the five environmental variables as explanatory variables. Akaike's information criteria (AIC) were used to test the goodness of fit of the estimated statistical models. To remove the possible effects of variation in abundance among samples, a rarefaction method was used to standardize species richness per number of individuals. Redundancy analysis (RDA) was used to determine the relative importance of environmental variables associated with the carabid species assemblages. The significance of environmental variables associated with the carabid assemblage was tested using a permutation test $(4,999$ permutations). To reveal the significance of the relationship between environmental variables and assemblages, we chose the optimum model using the command "ordistep" in package "vegan". The "ordistep" selected two environmental variables "area" and "understory cover". The number of individuals in each species was $\log (\mathrm{x}+0.1)$ transformed in RDA. We used R4.0.2 software for these analyses (R Development Core Team, 2020).

\section{Carabid beetles in natural broadleaf forest, natural mixed} forest and conifer plantation at Furano

\section{Study area and sampling}

We investigated the distribution of carabid beetles in three types of forests located at Furano in central Hokkaido, northern Japan: (1) natural broadleaf forest, (2) natural mixed forest and (3) conifer plantation (Table 1). The areas were 6.9 ha for the natural broadleaf forest, 3.4 ha for the natural mixed forest and 4.3 ha for the conifer plantation. Ground beetles were sampled using the same methods as described above. Samples were collected at 2-week intervals from 16 June to 31 October 2008 and
6 June to 20 October 2009. Here, we focused on the species of carabid characteristic of each type of forest, because we only had one replicate for each types of forest.

\section{Altitudinal distributions of two forest specialists in six mountain forests on Hokkaido}

Study area and sampling

We analysed the altitudinal distributions of two forest specialists, D. gehinii and P. kolbei, which were collected from six mountain forests by the Laboratory of Entomology at Obihiro University of Agriculture and Veterinary Medicine. The six mountains and years sampled are as follows: (1) Mt. Tokachi-Poroshiri (1986), (2) Mt. Fushimi (1987), (3) Mt. Memuro (1983), (4) Mt. Shari (1983), (5) Mt. Yûbari (1981) and (6) Mt. Rakko (1995). These mountains are located in central and eastern Hokkaido (Table 2). We classified the samples collected into three groups based on their altitudinal distributions: (1) low altitudes (below $700 \mathrm{~m}$ ) (Mt. Tokachi-Poroshiri: 2 sites, Mt. Fushimi: 1 site, Mt. Memuro: 2 sites, Mt. Shari: 2 sites, Mt. Yûbari: 2 sites, Mt. Rakko: 2 sites), (2) middle altitudes (701-1400 m) (Mt. Tokachi-Poroshiri: 5 sites, Mt. Fushimi: 4 site, Mt. Memuro: 4 sites, Mt. Shari: 4 sites, Mt. Yûbari: 2 sites, Mt. Rakko: 4 sites), (3) high altitudes (above 1,400 m) (Mt. Tokachi-Poroshiri: 3 sites, Mt. Fushimi: 4 site, Mt. Memuro: 2 sites, Mt. Shari: 4 sites, Mt. Yûbari: 1 site, Mt. Rakko: 1 site). When there were several sites for a group, the average number of individuals was divided by the number of sites. At low altitudes, the dominant vegetation making up the canopy was that of mixed forest consisting of broadleaf (Alnus maxinowiczii Callier, Betula platyphylla Sukaczev and Populus suaveolens Fisch) and coniferous trees [Picea jezoensis (Siebold et Zucc) and Abies sachalinensis (Fr. Schmidt)] except on Mt. Rakko where the broadleaf forests consist of Ulmus davidiana var. japonica Nakai and Acer pictum subsp. mono (Maxim.) (Table 2). The dominant vegetation making up the canopy at middle altitudes was mixed forest with broadleaf (A. maxinowiczii, Betula ermanii Cham., and Quercus crispula Blume) and coniferous trees $[P$. jezoensis, A. sachalinensis and Picea glehnii (Fr. chmidt)] except on Mt. Rakko where the broadleaf forests consist 
Table 3. Species and numbers of carabid beetles collected in secondary broadleaf forest and mixed forests and conifer (Sakhalin fir) plantations at Obihiro.

\begin{tabular}{lcccc}
\hline Species & Bro & Mix & Con & Total \\
\hline Cychrus morawitzi Gehin & 61 & 31 & 5 & 97 \\
Calosoma inquisitor cyanescens Motschulsky & 10 & 1 & 0 & 11 \\
Carabus conciliator hokkaidensis Lapouge & 48 & 46 & 174 & 268 \\
Leptocarabus arboreus arboreus (Lewis) & 80 & 0 & 0 & 80 \\
Leptocarabus opaculus opaculus (Putzeys) & 938 & 404 & 84 & 1426 \\
Procrustes kolbei (Roeschke) & 2 & 0 & 0 & 2 \\
Damaster blaptoides rugipennis Motschulsky & 33 & 38 & 78 & 149 \\
Pterostichus subovatus (Motschulsky) & 2 & 2 & 0 & 4 \\
Pterostichus adstrictus Eschscholtz & 13 & 13 & 49 & 75 \\
Pterostichus thunbergii Morawitz & 171 & 226 & 819 & 1216 \\
Pterostichus orientalis jessoensis Tschitscherine & 22 & 17 & 82 & 121 \\
Colpodes daisentsuzanus Nakane & 4 & 1 & 1 & 6 \\
Synuchus nitidus (Motshulsky) & 1 & 0 & 2 & 3 \\
Synuchus cycloderus (Bates) & 6 & 0 & 0 & 6 \\
Synuchus melantho (Bates) & 2 & 8 & 2 & 12 \\
\hline Number of individuals & 1393 & 787 & 12963476 \\
\hline Total number of species & 15 & 11 & 10 & 15 \\
\hline
\end{tabular}

Bro - secondary broadleaf forest; Mix - secondary mixed forest; Con - Conifer (Sakhalin fir) plantation.

of Sorbus commixta Hedl. and B. platyphylla (Table 2). At high altitudes, the dominant trees was Betula ermanii Cham. and Pinus pumila Regel (Table 2). The dominant species in the understory at low and middle altitudes was Sasa senanensis Rehder (Mt. Tokachi-Poroshiri, Mt. Fushimi and Mt. Memuro) and Sasa kurilensis Makino et Shibata (Mt. Shari, Mt. Yûbari and Mt. Rakko) (Table 2). The understory at high altitudes was dominated by Empetrum nigrum japonicum $\mathrm{K}$. Koch and Vaccinium vitis-udaea $\mathrm{L}$ (Table 2). Ground beetles were sampled using the same methods as described above. Samples were collected at 2-week intervals from June to October each year.

\section{RESULTS}

\section{Carabid beetles in secondary broadleaf forests, mixed forests and conifer plantations at Obihiro}

\section{Species richness and abundance}

A total of 3,476 carabid beetles consisting of 15 species in 6 genera was caught (Table 3). The number of individuals was highest in the secondary broadleaf forests $(1,393)$, followed by the conifer (Sakhalin fir) plantations $(1,296)$ and the secondary mixed forests (787). We collected 15 species in the secondary broadleaf forests, 11 species in the secondary mixed forests and 10 species in the conifer (Sakhalin fir) plantations. P. kolbei was caught only in the largest broadleaf forests at the highest altitudes in the area studied. Leptocarabus opaculus opaculus (Putzeys) was the most abundant (1,426 individuals, $41.0 \%$ of the total catch), followed by Pterostichus thunbergii Morawitz (1,216 individuals, $35.0 \%$ of the total catch), together making up $76.0 \%$ of the total catch. Leptocarabus opaculus opaculus was most abundant in the secondary broadleaf forests and very rare in the conifer plantations. Carabus conciliator hokkaidensis Lapouge and $P$. thunbergii were abundant in the conifer plantations, accounting for $65.0 \%$ and $67.0 \%$ of the total catch in each, respectively.
Table 4. GLM results of the species richness and number of individuals of carabids.

\begin{tabular}{|c|c|c|c|c|}
\hline Response variable & Estimate & Std. error & $z$ value & $\mathrm{Pr}$ \\
\hline No. of individuals & & & & - \\
\hline canopy & -0.817396 & 0.010237 & -79.844 & $* * *$ \\
\hline understory & -0.641410 & 0.004822 & -133.020 & $* * *$ \\
\hline moisture & 3.116207 & 0.028425 & 109.628 & $* * *$ \\
\hline area & 0.498932 & 0.005282 & 94.465 & $* * *$ \\
\hline forest type Mix & -1.125294 & 0.117318 & -9.592 & $* * *$ \\
\hline forest type Con & -5.618423 & 0.254746 & -22.055 & $* * *$ \\
\hline \multicolumn{5}{|l|}{ Species } \\
\hline (NULL) & - & - & - & - \\
\hline
\end{tabular}

Forest type Mix - mixed forests; forest type Con - conifer plantations; $^{* * *}-\mathrm{p}<0.001$.

\section{Environmental variables and carabid occurrence}

The canopy cover was moderately thin $(55-65 \%)$ in the conifer (Sakhalin fir) plantations but moderately dense $(70-85 \%)$ in the secondary broadleaf forests and the secondary mixed forests (Table 1). The dominant species in the canopy cover were $A$. sachalinensis (Sakhalin fir) in the conifer plantations; $Q$. crispula and Tilia japonica Simonk in the secondary broadleaf forests; and $Q$. crispula and $A$. sachlainensis in the secondary mixed forests. The understory was dense (90-100\%) in the conifer (Sakhalin fir) plantations and moderately dense (70-85\%) in the secondary broadleaf forests and secondary mixed forests (Table 1). The dominant species in the understory was dwarf bamboo $S$. senanensis in all types of forest.

GLM models for species richness and numbers of carabids are presented in Table 4. All environmental variables were associated with the numbers of carabids. These results may be due to the large number of L.o.opaculus at one site in the broad leaf forest and P.thunbergii in conifer plantations. There were no environmental variables associated with the species richness of carabids. However, when the number of species recorded was standardized by rarefaction in terms of numbers of individuals, species richness in the secondary broadleaf forests was higher than in other types of forest (Fig. 1).

\section{Carabid assemblages}

A total of $72.2 \%$ of the carabid species-environmental associations was accounted for by two axes of the RDA. The study sites are located along the first and second axes

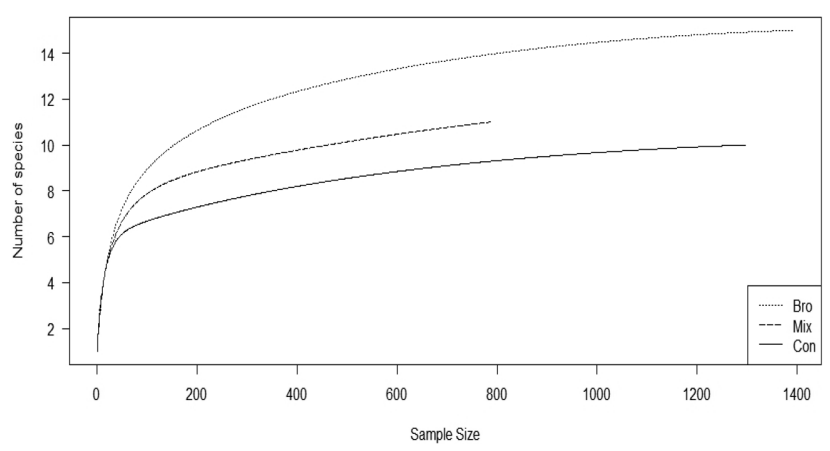

Fig. 1. Rarefaction curves of species richness for each type of forest at Obhiro. Bro - secondary broadleaf forest; Mix - secondary mixed forest; Con - conifer (Sakhalin fir) plantation. 


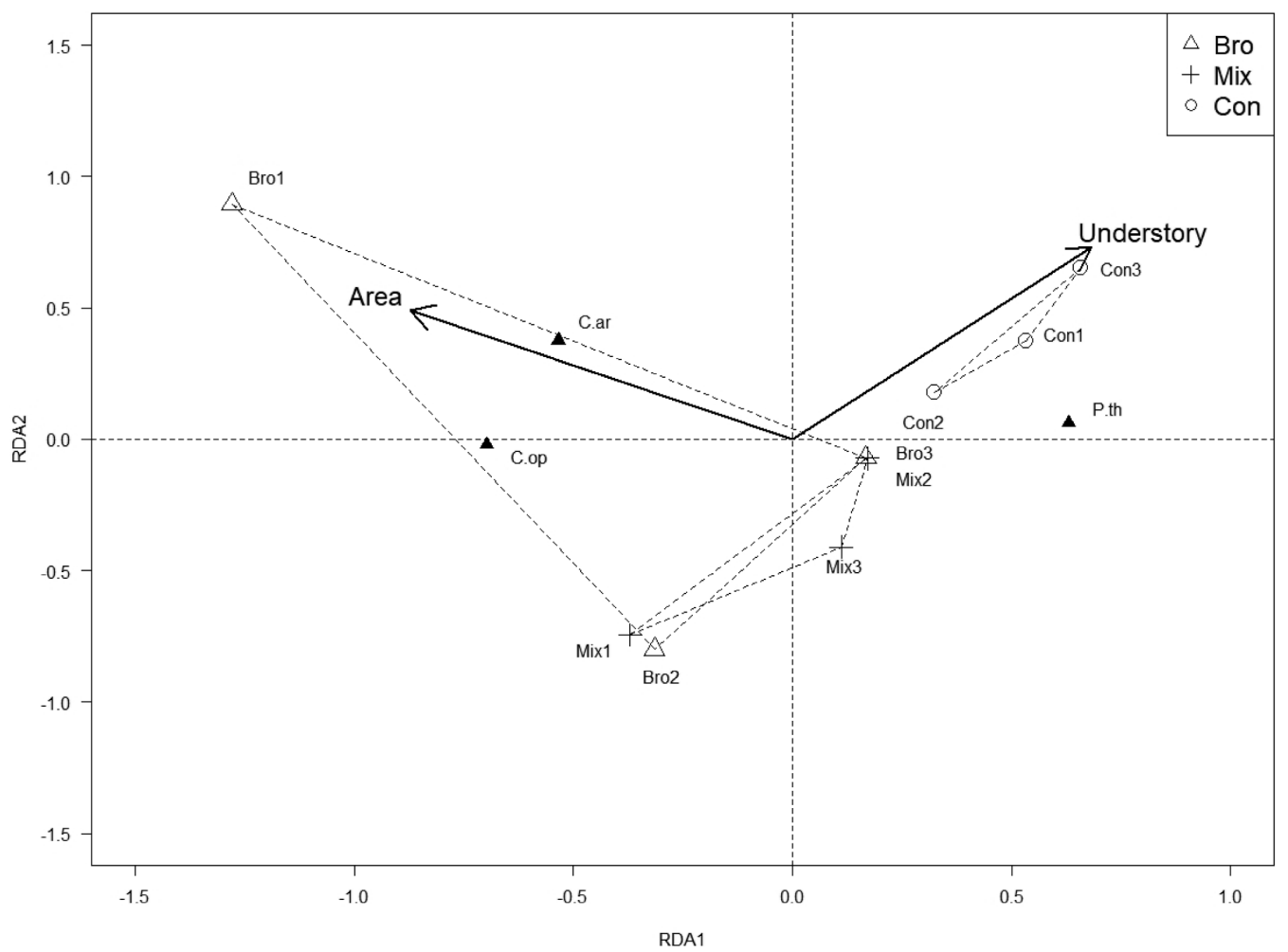

Fig. 2. Redundancy analysis (RDA) of carabid beetle-environmental variables biplot for Obihiro. L.ar - Leptocarabus arboreus arboreus; L.op - Leptocarabus opaculus opaculus; P.th - Pterostichus thunbergii; Bro - secondary broadleaf forest; Mix - secondary mixed forest; Con - conifer (Sakhalin fir) plantation.

in terms their area and understory cover (Fig. 2), with sites with large areas on the left of the diagram and those with high understory cover on the right. The RDA analysis indicates that the carabid assemblages differed significantly among the different types of forest $(p<0.05)$ and the structure of the carabid assemblages is significantly associated with area and understory cover $(p<0.001$ and $p<0.01$, respectively). The RDA diagram also indicates that two species [Leptocarabus a. arboreus (Lewis) and L. o. opaculus] are associated with area, and $P$. thunbergii with understory cover (Fig. 2).

\section{Carabid beetles in natural broadleaf forest, natural mixed forest and conifer plantation at Furano}

Species composition, species richness and abundance

A total of 2,684 individuals consisting of 21 species in 10 genera were caught at Furano (Table 5). The percentage of the total catch made up of the predominant species in the three types of forest is shown in Fig. 3. The percentage of the total catch made up of Cychrus morawitzi Gehin and Damaster gehinii was highest in both the natural broadleaf forest (59.5\% and $53.0 \%$, respectively) and natural mixed forest (31.6\% and $44.8 \%$, respectively) and low in the conifer plantation ( $8.9 \%$ and $2.2 \%$, respectively). The percentages of the total catch made up of L. o. opaculus were remarkably high in the natural broadleaf forest $(80.8 \%)$ and low in the natural mixed forest $(10.9 \%)$ and conifer plantation $(8.2 \%)$. The percentages of $P$. thunbergii were $51.6 \%$ in the natural mixed forest, $30.9 \%$ in the conifer plantation and $17.5 \%$ in the natural broadleaf forest.
The canopy cover was thin ( $35 \%$ and $30 \%$, respectively) in the natural broadleaf forest and natural mixed forest. The dominant species of trees in the canopy were mainly Acer pictum Thunb and Q. crispula in the natural broadleaf for-

Table 5. Species and numbers of carabid beetles in natural broadleaf forest and mixed forest and conifer (Sakhalin fir) plantation at Furano.

\begin{tabular}{lccccc}
\hline Species & NB & NM & PL & Total \\
\hline Cychrus morawitzi Gehin & 94 & 50 & 14 & 158 \\
Leptocarabus opaculus opaculus (Putzeys) & 1050 & 142 & 107 & 1299 \\
Damaster gehinii (Faimaire) & 71 & 60 & 3 & 134 \\
Damaster blaptoides rugipennis Motschulsky & 154 & 217 & 54 & 425 \\
Leistus niger alecto Bates & 11 & 5 & 3 & 19 \\
Pterostichus samurai (Lutshnik) & 0 & 0 & 1 & 1 \\
Pterostichus subovatus (Motschulsky) & 9 & 0 & 7 & 16 \\
Pterostichus adstrictus Eschscholtz & 19 & 2 & 23 & 44 \\
Pterostichus thunbergii Morawitz & 191 & 564 & 338 & 1093 \\
Pterostichus orientalis jessoensis Tschitscherine & 10 & 12 & 29 & 51 \\
Colpodes daisetsuzanus Nakane & 57 & 4 & 2 & 63 \\
Colpodes lampros Bates & 1 & 0 & 0 & 1 \\
Synuchus nitidus (Motschulsky) & 203 & 144 & 259 & 606 \\
Synuchus cycloderus (Bates) & 10 & 20 & 30 & 60 \\
Synuchus melantho (Bates) & 17 & 37 & 38 & 92 \\
Synuchus congruus (Morawitz) & 0 & 3 & 3 & 6 \\
Synuchus arcuaticollis (Motschulsky) & 2 & 0 & 0 & 2 \\
Amara sp. & 1 & 0 & 0 & 1 \\
Anisodactylus punctatipennis Morawitz & 0 & 0 & 1 & 1 \\
Harpalus quadripunctatus ainus Habu et Baba & 8 & 0 & 1 & 9 \\
Trichotichnus longitarsis Morawitz & 1 & 0 & 0 & 1 \\
\hline Number of individuals & 1406 & 816 & 462 & 2684 \\
\hline Number of species & 18 & 13 & 17 & 21 \\
\hline
\end{tabular}

NB - natural broadleaf forest; NM - natural mixed forest; PL - conifer plantation. 


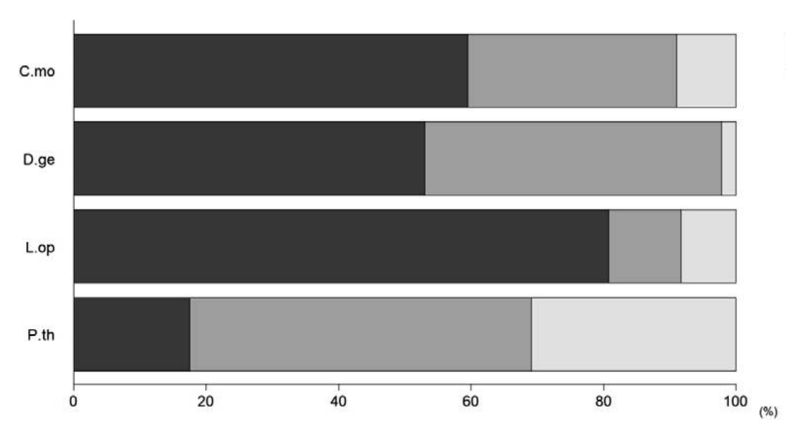

Fig. 3. The percentages of the total catch of four species carabids caught in the natural broadleaf forest, natural mixed forest and conifer (Sakhalin fir) plantation at Furano. C.mo - Cychrus morawitzi; D.ge - Damaster gehinii; L.op - Leptocarabus opaculus opaculus; P.th - Pterostichus thunbergii; NB - natural broadleaf forest; NM natural mixed forest; $\mathrm{PL}-$ conifer plantation.

est; A. sachalinensis and B. maximowicziana in the natural mixed forest; and $A$. sachalinensis in the conifer plantation. The understory cover was dense $(80 \%)$ in the natural broadleaf forest, moderately thin $(55 \%)$ in the natural mixed forest and very thin $(10 \%)$ in the conifer plantation. The dominant species in the understory were Pachysandra terminalis Siebold et Zucc and S. senanensis in the natural broadleaf forest and natural mixed forest, and S. senanensis in the conifer plantation.

\section{Altitudinal distributions of two forest specialists in six mountain forests on Hokkaido}

In our survey of the collections of two forest specialists in six mountain forests, the numbers of $D$. gehinii and $P$. kolbei were $174(3.7 \%)$ and 4,525 (96.3\%), respectively, with $D$. gehinii clearly the rarer. The percentage of these two forest specialists in the three categories of altitude in the six mountain forests are shown in Fig. 4. On the whole, the percentages of $D$. gehinii appears to be high at low altitudes (below $700 \mathrm{~m}$ ). On Mt. Rakko, however, the percentages of $D$. gehinii were very low at low altitudes and comparatively high at high altitudes, this difference, however, may be associated with differences in the environmental conditions at the lowest altitudes on the six mountains. On the other hand, the percentages of $P$. kolbei were very high at middle (701-1,400 m) to high altitudes (above 1,400 m) and low at low altitudes (below $700 \mathrm{~m}$ ).

\section{DISCUSSION}

\section{Carabid assemblage composition, species richness, abundance and habitat preference}

The species compositions recorded in the present study are similar to those previously reported on Hokkaido in broadleaf forests by Hori (2003) and conifer plantations by Kaizuka \& Iwasa (2015). Damaster gehinii was caught at Furano but not Obihiro; this is mostly due to differences in the types of forest at Furano and Obihiro. According to Imura \& Mizusawa (2013), D. gehinii occurs in a wide range of habitats and is abundant in broadleaf forests and mixed forests of broadleaf and coniferous trees. Hori (2003) classifies D. gehinii as a forest specialist and notes that it is rare, found only in large natural broadleaf forests. At Furano (Table 5, Fig. 3), this species primarily prefers both natural broadleaf forest and natural mixed forest. Forest specialist species disappear after logging of natural forests and replanting with coniferous trees (Magura et
(1) Mt.Yûbari

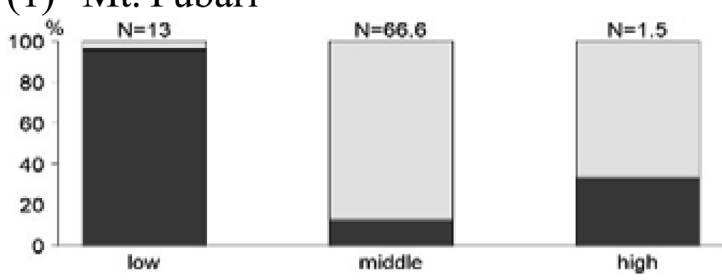

(3) Mt. Shari

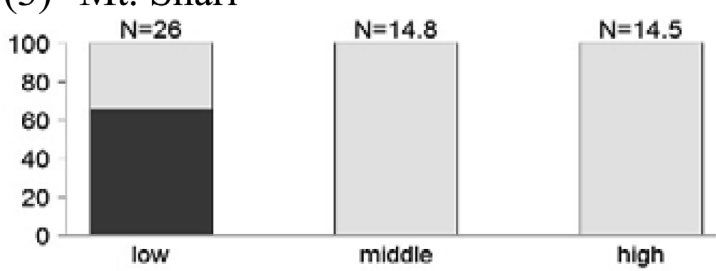

(5) Mt.Fushimi

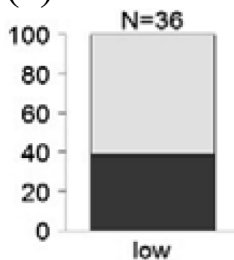

low

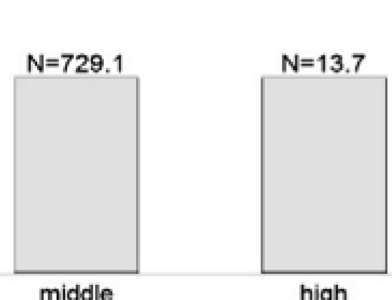

\section{(2) Mt.Memuro}
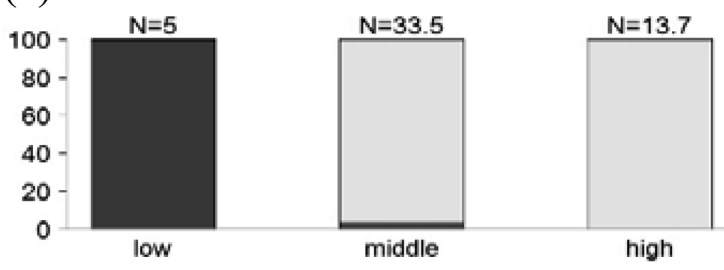

(4) Mt. Tokachi-Poroshiri

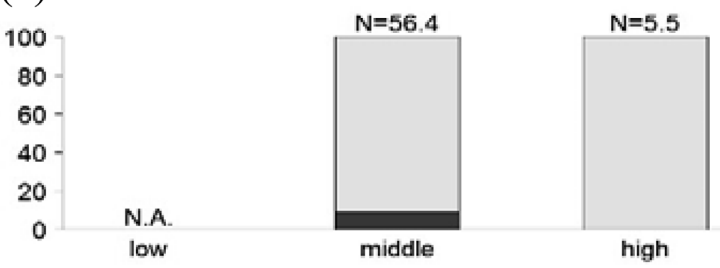

(6) Mt. Rakko

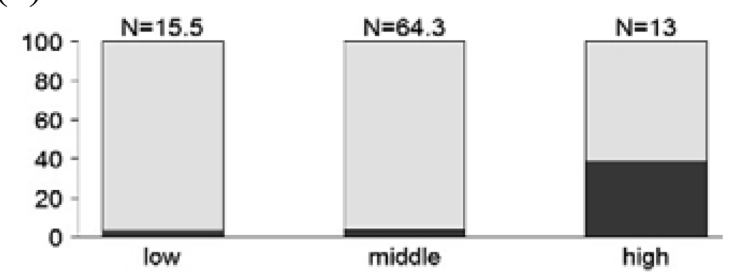

-Damaster gehinii Procrustes kolbei

Fig. 4. The percentage of the catch that consisted of individuals of $D$. gehinii and $P$. kolbei at three different altitudes in six mountain forests. N.A. - not available; low - below 700 m; middle - $701 \mathrm{~m}-1,400 \mathrm{~m}$; high - above 1,400 m. 
al., 2002, 2003; Yu et al., 2006). The fact that D. gehinii was not caught at Obihiro indicates that this species is not able to survive in secondary forests on mountains at low altitudes, which were repeatedly logged and planted. Procrustes kolbei prefers mature forest (Imura \& Mizusawa, 2013). Site 1 where $P$. kolbei was caught is located in a larger area of forest and at a higher altitude than the other sites (Table 1). In addition, this species was caught mainly at middle to high altitudes, with few caught at altitudes below $700 \mathrm{~m}$ (Table 5), whereas the main habitat of $D$. gehinii seems to be at low altitudes (Fig. 4). When evaluating carabid beetles in secondary broadleaf forest and secondary mixed forest of broadleaf and conifers in mountainous areas, attention should be paid not only to their diversity and abundance but also to the presence and altitudinal distributions of forest specialists.

Comparisons of the diversity of carabid assemblages in broadleaf forest and conifer plantations indicate a lower carabid diversity in conifer plantations (Butterfield et al., 1995; Fahy \& Gormally, 1998; Magura et al., 2003; Yu et al., 2006). The rarefaction analysis (Fig. 1) confirms the above as the number of species was least in the conifer (Sakhalin fir) plantations. The mixed forests may be more suitable for some species than the conifer (Sakhalin fir) plantations. Leptocarabus arboreus arboreus and L. o. opaculus are forest generalists, which inhabit a wide range of forests (Kimoto \& Yasuda, 1995; Imura \& Mizusawa, 2013). However, Furuta (1983) shows that L. o. opaculus is more abundant in natural broadleaf forests than natural mixed forests and conifer (Sakhalin fir) plantations. The RDA results indicate that $L$. a. arboreus and $L$. o. opaculus were associated with secondary broadleaf forests at Obihiro (Fig. 2) and the latter was abundant in natural broadleaf forest at Furano (Fig. 3), therefore, it is likely that these species prefer broadleaf forest. The abundance of $P$. thunbergii in the conifer (Sakhalin fir) plantations at Obihiro (Table 3 ) indicates this species may not be sensitive to deforestation and can survive in conifer plantations. This is supported by the result that this species made up a relatively high percentage of the total catch in conifer (Sakhalin fir) plantation at Furano (Fig. 3).

\section{Environmental variables and carabid occurrence}

Niemelä et al. (1988) report no differences in the species assemblages in coniferous forests larger than 30 ha and smaller than 5 ha. The results presented on associations with forests of different sizes is similar to the above and may indicate there is no distinct difference in carabid assemblages recorded in forests of different sizes including broadleaf forests. However, strict forest specialists are found only in large, contiguous forests (Halme \& Niemelä, 1993). Discovery of a forest specialist $P$. kolbei at only one site in a large broadleaf forest may indicate that area is an important factor for this forest specialist. That there are significant associations with large broadleaf forest for two forest generalist species (L. a. arboreus and L.o. opaculus) may be due to the high bio-productivity of large forests rather than area for these two species. It is reported that diversity and abundance of carabid beetles are associated with various environmental variables, such as, soil moisture (Butterfield et al., 1995), soil pH (Baguette \& Gerard, 1993), vegetation structure (Ings \& Hartley, 1999) and shad or openings in the canopy (Niemelä \& Halme, 1992). Greenslade (1964) indicates that the presence of a dense understory inhibits the movement of carabid beetles. After logging and planting, bamboo grass is likely to invade disturbed areas on Hokkaido, potentially resulting in a dense understory, the cover of which is estimated to be greatly affected by canopy cover, which is dependent on the tree density in the plantation. Pterostichus thunbergii, which was associated with understory cover (Fig. 2), may be able to colonize conifer (Sakhalin fir) plantations where the understory cover is high. However, in a previous study (Kaizuka \& Iwasa, 2015), some forest generalists such as Pterostichus orientalis jessoensis Tschitsherine and Synuchus melantho Bates are reported as very abundant in Sakhalin fir plantations where the understory cover is distinctly lower than that recorded in the present study, due to high tree density. Yasuda \& Sato (1992) report that Synuchus sp. is very abundant in conifer (Sakhalin fir) plantations where the understory cover is very sparse. Thus, even in plantations of the same species of tree, carabid assemblages may differ because of difference in the understory cover. In particular, there may be an increase in the abundance of certain species in very dense conifer plantation due to a sparse understory cover.

\section{Implications for conservation and forest management}

The carabid assemblages are poorer in plantations consisting of only one species of tree (Magura et al., 2002, 2003) and biodiversity is higher in mixed tree plantings (Butterfield \& Benitez-Malvido, 1992). In terms of the diversity of forest generalists, secondary mixed forests of broadleaf and conifer trees may be potential substitutes for secondary broadleaf forests. The forestry practice of leaving broadleaf forests or stands in conifer plantations may also provide a more favourable environment for carabids. However, it is important to maintain natural, semi-natural, or mature forests for some forest specialists. In mountain forests in the Hidaka range, where the sites studied at Obihiro are located, logging and afforestation mainly occurs at altitudes below about $700-800 \mathrm{~m}$ because forestry operations are difficult at high altitudes due to steep slopes. In particular, therefore, maintenance of natural or seminatural broadleaf forests at low altitudes is essential for conserving the population of forest specialists, such as, $D$. gehinii. However, natural or semi-natural mixed forests of broadleaf and conifer trees at middle to high altitudes are an important habitat for $P$. kolbei.

Previous studies report that a mosaic of forest patches increases the diversity at the landscape level (Butterfield \& Benitez-Malvido, 1992; Koivula, 2002a; Magura et al., 2002, 2003). In particular, in areas where forestry operations are frequent, maintenance of a connected mosaic of various habitats may result in a rich diversity and abundance of carabid beetles. Magura et al. (2000) indicate that creating gaps by thinning spruce stands encourages re- 
colonization by the native understory. Forest management should also consider tree density, which affects both the understory and canopy cover. These management practices should protect the carabid populations and forest ecosystem.

ACKNOWLEDGEMENTS. We wish to express our thanks to T. Oshida and N. Kumano of Obihiro University of Agriculture and Veterinary Medicine and T. Nakamura of Hirosaki University for their valuable suggestions. Our thanks are also due to G.A. Hill of Obihiro University of Agriculture and Veterinary Medicine for checking the English of this manuscript.

\section{REFERENCES}

Baguette M. \& Gerard S. 1993: Effects of spruce plantations on carabid beetles in southern Belgium. - Pedobiologia 37: 129-140.

BAKER S.C. 2006: A comparison of litter beetle assemblages (Coleoptera) in mature and recently clearfelled Eucalyptus obliqua forest. - Aust. J. Entomol. 45: 130-136.

Butterfield J. \& Benitez-Malvido J. 1992: Effect of mixedspecies tree planting on the distribution of soil invertebrates. In Canell M.G.R., Malcolm D.C. \& Robertson P.A. (eds): The Ecology of Mixed-Species Stands of Trees. Blackwell, London, pp. 255-265.

Butterfield J., Luff M.L., Baines M. \& Eyre M.D. 1995: Carabid beetle communities as indicators of conservation potential in upland forests. - For. Ecol. Manag. 79: 63-77.

CobB T.P., Langor D.W. \& Spence J.R. 2007: Biodiversity and multiple disturbances: boreal forest ground beetle (Coleoptera: Carabidae) responses to wildlife, harvesting, and herbicide. Can. J. For. Res. 37: 1310-1323.

da Silva P.M., Aguiar C.A.S., Niemelä J., Sousa J.P. \& SerRANO A.R.M. 2008: Diversity patterns of ground-beetles (Coleoptera: Carabidae) along a gradient of land-use disturbance. - Agric. Ecosyst. Environ. 124: 270-274.

Do Y., Lineman M. \& Joo G.J. 2012: Impacts of different landuse patterns on the carabid beetle diversity and species assemblages in South Korea. - Ekoloji 21: 9-17.

Duchesne L.C., Lautenschlager R.A. \& Bell F.W. 1999: Effects of clear-cutting and plant competition control methods on carabid (Coleoptera: Carabidae) assemblages in northwestern Ontario. - Environ. Monit. Assess. 56: 87-96.

Eyre M.D., LotT D.A. \& Garside A. 1996: Assessing the potential for environmental monitoring using ground beetles (Coleoptera: Carabidae) with riverside and Scottish data. - Ann. Zool. Fenn. 33: 157-163.

FAHY O. \& GoRmally M. 1998: A comparison of plant and carabid beetle communities in an Irish oak woodland with a nearby conifer plantation and clearfelled site. - For. Ecol. Manag. 110: $263-273$.

FINCH O.D. 2005: Evaluation of mature conifer plantations as secondary habitat for epigeic forest arthropods (Coleoptera: Carabidae; Araneae). - For. Ecol. Manag. 204: 23-36.

Fujita A., Maeto K., Kagawa Y. \& Ito N. 2008: Effects of forest fragmentation on species richness and composition of ground beetles (Coleoptera: Carabidae and Brachinidae) in urban landscapes. - Entomol. Sci. 11: 39-48.

Fuller R.J., Oliver T.H. \& LeAther S.R. 2008: Forest management effects on carabid beetle communities in coniferous and broadleaved forests: implications for conservation. - Insect Conserv. Divers. 1: 242-252.
FURUTA K. 1983: Relationship between community structure of carabid beetle and forest fauna in Ishikari. - Shinrinbunkakenkyu 4: 61-68 [in Japanese].

Greenslade P.J.M. 1964: Pitfall trapping as a method for studying populations of Carabidae (Coleoptera). - J. Anim. Ecol. 33: 301-310.

Halme E. \& Niemelä J. 1993: Carabid beetles in fragments of coniferous forest. - Ann. Zool. Fenn. 30: 17-30.

Heliölä J., KoIvUla M. \& Niemelä J. 2001: Distribution of carabid beetles (Coleoptera, Carabidae) across a boreal forestclearcut ecotone. - Conserv. Biol. 15: 370-377.

HoKKaIDO 2018: Hokkaido Forestry Statistics, Japan. URL: http://www.pref.hokkaido.lg.jp/sr/sum/kcs/rin-toukei/27rtk. htm (last accessed 20 Aug 2019).

Hori S. 2003: Characteristics of carabid beetles inhabiting in the isolated forest. - Bull. Hist. Mus. Hokkaido 31: 15-28 [in Japanese].

Humphrey J.W., Hawes C., Peace A.J., Ferris-Kaan R. \& Jukes M.R. 1999: Relationships between insect diversity and habitat characteristics in plantation forests. - For. Ecol. Manag. 113: $11-21$.

Imura Y. \& Mizusawa K. 2013: The Carabus of Japan. RopponAshi Entomological Books, Tokyo, 368 pp [in Japanese].

IngS T.C. \& HaRTLEY S.E. 1999: The effects of habitat structure on carabid communities during the regeneration of a native Scottish forest. - Forest. Ecol. Manag. 119: 123-126.

Jukes M.R., Peace A.J. \& Ferris R. 2001: Carabid beetle communities associated with coniferous plantations in Britain: the influence of site, ground vegetation and stand structure. - For. Ecol. Manag. 148: 271-286.

Kaizuka J. \& Iwasa M. 2015: Carabid beetles (Coleoptera: Carabidae) in coniferous plantations in Hokkaido, Japan: effects of tree species and environmental factors. - Entomol. Sci. 18: 245-253.

Karen M., O’Halloran J., Breen J., Giller P., Pithon J. \& Kelly T. 2008: Distribution and composition of carabid beetle (Coleoptera, Carabidae) communities across the plantation forest cycle - Implications for management. - For. Ecol. Manag. 256: 624-632.

Kiмото S. \& Yasuda N. 1995: Ground Beetles in Hokkaido. A Bioenvironmental Approach. Tokai University Press, Tokyo, 315 pp. [in Japanese].

Klimaszewski J., Langor D.W., Work T.T., Pelletier G., HamMOND H.E.J. \& GeRMAIN C. 2005: The effects of patch harvesting and site preparation on ground beetles (Coleoptera, Carabidae) in yellow birch dominated forests of southeastern Quebec. - Can. J. For. Res. 35: 2616-2628.

Korvula M. 2002a: Boreal carabid-beetle (Coleoptera, Carabidae) assemblages in thinned uneven-aged and clear-cut spruce stands. - Ann. Zool. Fenn. 39: 131-149.

KoIvUla M. 2002b: Alternative harvesting methods and boreal carabid beetles (Coleoptera, Carabidae). - For. Ecol. Manag. 167: 103-121.

Koivula M. \& Spence J.R. 2006: Effects of post-fire salvage logging on boreal mixed-wood ground beetle assemblages (Coleoptera, Carabidae). - For. Ecol. Manag. 236: 102-112.

Kotze D.J. \& SAmwAYs M.J. 1999: Invertebrate conservation at the interface between the grassland matrix and natural Afromontane forest fragments. - Biodiv. Conserv. 8: 1339-1363.

Lange M., Türke M., Pašalić E., Boch S., Hessenmöller D., Müller J., Prati D., Socher S.A., Fischer M., Weisser W.W. ET AL. 2014: Effects of forest management on ground-dwelling beetles (Coleoptera, Carabidae, Staphylinidae) in Central Europe are mainly mediated by changes in forest structure. For. Ecol. Manag. 329: 166-176. 
LÖVEI G.L. \& SundERLAND K.D. 1996: Ecology and behavior of ground beetles (Coleoptera: Carabidae). - Annu. Rev. Entomol. 41: 231-256.

LÖVei G.L., Magura T., Tóthmérész B. \& KöDÖBÖcz V. 2006: The influence of matrix and edges on species richness patterns of ground beetles (Coleoptera: Carabidae) in habitat islands. Glob. Ecol. Biogeogr. 15: 283-289.

Magura T. 2002: Carabids and forest edge: spatial and edge effect. - For. Ecol. Manag. 157: 23-37.

Magura T., Tóthmérész B. \& Bordán Z. 2000: Effects of nature management practice on carabid assemblages (Coleoptera: Carabidae) in a non-native plantation. - Biol. Conserv. 93: 95-102.

MAGURA T., KöDÖBÖCZ V. \& TÓTHMÉRÉSz B. 2001a: Effects of habitat fragmentation on carabids in forest patches. - J. Biogeogr. 28: $129-138$.

Magura T., Tóthmérész B. \& MolnáR Z. 2001b: Edge effect on carabid assemblages along forest-grass transects. - Web Ecol. 2: 7-13.

Magura T., Elek Z. \& Tóthmérész B. 2002: Impacts of non-native spruce reforestation on ground beetles. - Eur. J. Soil Biol. 38: $291-295$.

Magura T., Tóthmérész B. \& Elek Z. 2003: Diversity and composition of carabids during a forestry cycle. - Biodiv. Conserv 12: $73-85$.

Ministry of Agriculture, Forestry and Fisheries 2018: Annual Report on Forest and Forestry in Japan. URL: https://www. rinya.maff.go.jp/j/kikaku/toukei/youran_mokuzi2018.html (last accessed 14 Nov 2019).

Müller M.M., Varama M., Heinonen J. \& Hallaksela A.M. 2002: Influence of insects on the diversity of fungi in decaying spruce wood in managed and natural forests. - For. Ecol. Manag. 166: 165-181.

Negro M., Vacchiano G., Berretti R., Chamberlain D.E., Palestrini C., Motta R. \& Rolando A. 2014: Effects of forest management on ground beetle diversity in alpine beech (Fagus sylvatica L.) stands. - For. Ecol. Manag. 15: 300-309.

NIEMELÄ J. 1997: Invertebrates and boreal forest management. Conserv. Biol. 16: 601-610.

Niemelä J. \& Halme E. 1992: Habitat associations of carabid beetles in fields and forests on the Åland Islands, SW Finland. Ecography 15: 3-11.

Niemelä J., Haila Y., Halme E., Lahti T., Pajunen T. \& Puntila P. 1988: The distribution of carabid beetles in fragments of old coniferous taiga and adjacent managed forest. - Ann. Zool. Fenn. 25: 107-119.

Niemelä J., Spence J.R., Langor D., Haila Y. \& Tukia H. 1994: Logging and boreal ground-beetle assemblage on two continents: implications for conservation. In Gaston K., New T.R. \& Samways M. (eds): Perspectives on Insect Conservation. Intercept, Andover, pp. 29-50.

Niemelä J., Kotze J., Ashworth A., Brandmayr P., Desender K., New T., Penev L., Samways M. \& Spence J. 2000: The search for common anthropogenic impacts on biodiversity: a global network. - J. Insect Conserv. 4: 3-9.

Osawa N., Terai A., Hirata K., Nakanishi A., Makino A., SaKai S. \& SiBATA S. 2005: Logging impacts on forest carabid assemblages in Japan. - Can. J. For. Res. 35: 2698-2708.
Purtauf T., Roschewitz I., Dauber J., Thies C., TscharntKe T. \& WoLTERS V. 2005: Landscape context of organic and conventional farms: influences on carabid beetle diversity. - Agric. Ecosyst. Environ. 108: 165-174.

R Development Core Team 2020: $R$ : A Language and Environment for Statistical Computing. URL: https://www.r-project. org/ (last accesed 5 Feb 2020).

RaINIO J. \& Niemelä J. 2006: Comparison of carabid beetle (Coleoptera: Carabidae) occurrence in rain forest and human-modified sites in south-eastern Madagascar. - J. Insect Conserv. 10: $219-228$

Shibuya S., Kubota K. \& Ohsawa M. 2008: Effects of small scale management on biodiversity of an abandoned coppice forest in Japan: a case study on vegetation regeneration and ground beetle community. - Web Ecol. 8: 116-124.

Shibuya S., Kikvidze Z., Toki W., Kanazawa Y., Suizu T., Yajima T., Fujimori T., Mansournia M.R., Sule Z., Kubota K. et al. 2014: Ground beetle community in suburban Satoyama - A case study on wing type and body size under small scale management. - J. Asia-Pac. Entomol. 17: 775-780.

Ueno S., Kurosawa Y. \& Sato M. 1985: The Coleoptera of Japan in Color. Vol. 2. Hoikusha, Osaka, 479 pp. [in Japanese].

Ulyshen M.D., Hanula J.L., Horn S., Kilgo J.C. \& Moorman C.E. 2006: The response of ground beetles (Coleoptera: Carabidae) to selection cutting in a South Carolina bottomland hardwood forest. - Biodiv. Conserv. 15: 261-274.

Waltz A.E.M. \& Covington W.W. 2004: Ecological restoration treatments increase butterfly richness and abundance: mechanisms of response. - Restor. Ecol. 12: 85-96.

WERNER S.M. \& RAFFA K.F. 2000: Effects of forest management practices on the diversity of ground-occurring beetles in mixed northern hardwood forests of the Great Lakes Region. - For. Ecol. Manag. 139: 135-155.

Working Group for Biological Indicator Ground Beetles DaTABASE JAPAN 2015: Natural Woodlands Ground Beetles. URL: http://www.biwahaku.jp/research/data/gomimushi/kamei_list. html (last accessed 24 Oct 2019).

YASUDA N. \& SATO M. 1992: Insect Faunal Survey of Is. Rishiri and Is. Rebun and Sarobetsu Field. The Vertical Distribution of Ground Beetle Communities in Mt. Rebun, Is. Rebun, Hokkaido. Annual Report of Rishiri Municipal Museum, pp. 11-25. [in Japanese].

YU X.D., ZHOU H.Z. \& LuO T.H. 2002: Distribution patterns and their seasonal changes of Carabus beetles in Dongling Mountain region near Beijing. - Acta. Ecol. Sin. 22: 1724-1733.

Yu X.D., Luo T.H. \& ZHOU H.Z. 2006: Distribution of carabid beetles among regenerating and natural forest types in Southwestern China. - For. Ecol. Manag. 231: 169-177.

Yu X.D., Luo T.H. \& ZHou H.Z. 2008: Distribution of carabid beetles among 40-year-old regenerating plantations and 100-year-old naturally regenerated forests in Southwestern China. - For. Ecol. Manag. 255: 2617-2625.

Yu X.D., Luo T.H. \& ZHou H.Z. 2010: Distribution of grounddwelling beetle assemblages (Coleoptera) across ecotones between natural oak forests and mature pine plantations in North China. - J. Insect Conserv. 14: 617-662.

Received March 21, 2020; revised and accepted September 7, 2020 Published online October 13, 2020 